\title{
ESTIMATION OF THE MARKETING ACTIVITY OF BANKING STRUCTURES
}

\author{
Nestor Shpak¹, Ihor Kulyniak², Maryana Gvozd², Yuliya Malynovska³, \\ Włodzimierz Sroka ${ }^{4}$
}

\begin{abstract}
${ }^{1}$ Department of Management and International Business, Faculty of Economics and Management, Lviv Polytechnic National University, Stepana Bandery St. 12, 79000 Lviv, Ukraine

2 Department of Management of Organizations, Faculty of Economics and Management, Lviv Polytechnic National University, Stepana Bandery St., 12, 79000 Lviv, Ukraine

${ }^{3}$ Department of Foreign Trade and Customs, Faculty of Economics and Management, Lviv Polytechnic National University, Stepana Bandery St., 12, 79000 Lviv, Ukraine

${ }^{4}$ Department of Management, Faculty of Applied Sciences, WSB University, Cieplaka 1c, 41-300 Dąbrowa Górnicza, Poland \& North-West University, Private Bag X1290, Potchefstroom 2520, South Africa
\end{abstract}

Link to this article: https://doi.org/10.11118/actaun202068010229

Received: 26. 10. 2019, Accepted: 4. 12. 2019

To cite this article: SHPAK NESTOR, KULYNIAK IHOR, GVOZD MARYANA, MALYNOVSKA YULIYA, SROKA WŁODZIMIERZ. 2020. Estimation of the Marketing Activity of Banking Structures. Acta Universitatis Agriculturae et Silviculturae Mendelianae Brunensis, 68(1): 229-242.

\begin{abstract}
Well-designed marketing activities and the use of modern marketing tools can increase the competitiveness of banks on the market. Given this fact, the main purpose of the study is to develop theoretical and practical provisions for estimating the level of marketing activity of banking structures. This is based on the definition of the integral index and takes into account all the elements of the marketing-mix and their partial indicators. The urgency of solving this problem comes from the fact that it is precisely the estimation of the level of marketing activity of the banking structures that directs managers to make the appropriate adjustment of marketing activities and make use of modern marketing instruments that will increase the competitiveness of banks on the market (e.g. increase market share and expand the boundaries of the target segments, help to create a positive image of the bank and maintain its business reputation).

The article proposes a calculation methodology for bank marketing activity, which has been tested through the definition of the level of marketing activity of the leading Ukrainian banks. The computation of the level of bank's marketing activity is based on the calculation of the integral indicator by summarization the input statistics, that characterize the bank's marketing activity, with help of two methods: the standardization method and the hierarchy analysis method (Saaty method). The results of the expert survey were used for determining the weight of partial indicators within the hierarchy analysis method. Based on the results, the analyzed banks are ranked according to the level of their marketing activity in the investigated period, and a system of particular measures for raising the level of their marketing activity has been established.
\end{abstract}

Keywords: bank marketing activity, integral index, rating of the indicators, banking system, elements of the marketing-mix

\section{INTRODUCTION}

One of the elements that influence the effectiveness of banking structures is banking marketing activities. The reason is that well-designed marketing activities and the use of modern marketing tools can increase the competitiveness of banks on the market, i.e. increase market share and expand the boundaries of the target segments, create a positive image of the 
bank and maintain the reputation of the business, which reflect the relevance of the chosen research topic and the need for further research and effective measures to evaluate and improve the efficiency of bank marketing activity.

The modeling of bank marketing activity is necessary in order to ensure the efficient functioning of a bank and the banking system of the country as a whole, in particular for the timely formation of protection measures for marketing departments against external and internal destabilizing factors and to prevent them having a negative impact on the bank's activity. By comparing the bank's marketing expenses with its position in the ranking according to the level of marketing activity, one can estimate how effectively banks manage all the components of marketing and the effectiveness of implementing their marketing plans. It is also possible to estimate the impact of variables on the overall level of bank marketing activity in order to further optimize the distribution of marketing resources. It should also be noted that information on the effectiveness of bank marketing activities is very important for investors. This is due to the fact that a high level of marketing activities offers greater guarantees of the preservation and accumulation of investment funds. This issue is especially relevant in the conditions of high marketing and commercial risk and the instability of the financial market in Ukraine.

The issue has been widely analyzed in the literature. However, most scholars analyze the criteria for the effectiveness of bank marketing activities not based on a set of indicators, but a certain indicator, e.g. profitability (Melchinger, 1992). Consequently, a research gap may be observed, which our study aims to fill. Given the facts presented, the main purpose of the research is to develop theoretical and applied provisions for estimating the level of marketing activity of banking structures. We proposed a calculation methodology for bank marketing activity, which has been tested through the definition of the level of marketing activity of the leading Ukrainian banks.

The paper is structured as follows. Firstly, we present the theoretical background of our study. The theoretical deliberations presented in this part concentrate on the marketing activities of the banks. Secondly, we present the methodology that was applied in this research. The next part of our paper presents the results and discussion. Finally, we present the conclusions and limitations of our study.

\section{Literature Review}

Scientific literature highlights the importance of evaluating the effectiveness of banking activities. The results of the research showed that scientists have analyzed various aspects of the topic. In particular, the factors that influence the efficiency of banking activity are studied. Thus, Bakhanova
(2014) proved that the higher the efficiency of the marketing-mix, the higher the density of the links between marketing communication costs and the results of banking activities. In this context, Valentyn and Pavlov (2017) scientifically substantiated the novelty of marketing and financial interaction in the Ukrainian banking system. At the same time, the authors showed that, when comparing marketing costs with financial positions, it is possible to estimate how effectively the banks manage their financial resources, and the impact of marketing activities on the financial condition of the banks.

Csikósová et al. (2016) conducted an estimation of the quantitative indicators of marketing activities in the banking sector. They proposed the balanced scorecard which sets out goals for carrying out the strategy of the banks in terms of positive development for the future and improving the implementation of individual marketing activities. The results showed a lag in the growth rate compared to the overall market growth rate and a negative change in customer profitability. Khmarskyi and Pavlov (2016) proposed a new approach to determining the financial position of Ukrainian banks in both the long and short term. Using the European rating and national indexes, a new rating system was created. The authors classified the 20 largest Ukrainian banks by assets and divided them into relevant financial groups.

The need to use the classical tools of the 4P marketing in banking activity has been reinforced by the conclusions of numerous many scholars and researchers; however, each of them reveals different elements. In particular, Veselova (2014) examines the foreign experience of using classical marketing tools ("4P") to enhance competition on the banking market. Bakhanova (2014) states that in order for the marketing of banking products to be successful, it is necessary to use all means of the product promotion on the market. Other authors, e.g. Androniceanu et al. (2019) have investigated the correlation between the development of the private sector, including the banking one and the financial and fiscal policies.

Mullan et al. (2017), Alaeddin et al. (2018), as well as Sha and Mohamed (2017), analyze the prospects of introducing mobile banking as an innovative product, which is one of the elements of the marketing-mix. Similarly, Karyy and Krykavskyy (2016) revealed the problems of marketing transformation in the age of digitization and described the peculiarities of digital marketing. Furthermore, Feichtinger et al. (1994) describe the invention of dynamic optimal management models in advertising. Shpak et al. (2016) substantiated the importance of choosing the optimal direction of sales activity as one of the main areas of activity of the organization (in this case, of course, it refers to banks), the functioning of which should be full, synchronous and complementary. 
One should emphasize that it is advisable for the banking industry to invest in marketing potential, in particular social media, in order to gain a competitive advantage in providing banking services to its customers (Assensoh-Kodua, 2016; Puriwat and Tripopsakul, 2017; Pakurár et al., 2018 a, b). Social media is one of the most used digital platforms amongst today's youth and can be very valuable as a marketing tool to penetrate this cohort (Kot and Meyer, 2018). At the same time, however, banks should be able to change the procedure and policy of their marketing activities to meet the expectations and needs of the customers (Jafari, 2016; Androniceanu, 2017) and take care of marketing relations in the sector (Yoganathan et al., 2015); otherwise their existence on the financial market in the future will be threatened and experience increased risks (Meyer et al., 2019).

Due to the trend towards the consideration of behavioral aspects in revising traditional managerial concepts, the expectations and needs of customers are nowadays becoming the main issue of interest, including when it comes to the scope of marketing patterns in the banking sector. This trend is reflected by Kliestikova et al. (2019) who deal with the identification of the relevant brand value sources in the sector. According to these authors, in the case of banking brands, it is necessary to build brand value based on benefits and imageries as the main factors of subjectively perceived brand value sources.

The banking sector requires investments in marketing innovations, which should be synchronous with the development of market culture and the improvement of organizational learning processes (Mahmoud et al., 2016). For example, based on the example of a large bank in Kuwait, Roumieh et al. (2018) showed how e-marketing could be implemented more effectively to attract new customers and maintain the existing ones by critically assessing the viability of e-marketing strategies for the promotion of Islamic banking. Research on perceptions of marketing in social media and its comparison with the perception of other marketing forms used in the Slovak banking market, taking age differences into account, was undertaken by Vejačka (2017). Additionally, Al-alak (2014) describes the impact of marketing activities on the quality of relationships between clients and employees in the Malaysian banking sector. On the other hand, in some specific cases, the positive impact of innovations on marketing activities in the banking sector was not proven. Kliestikova and Kovacova (2017) carried out a case study of innovation perception in the scope of banking brands in the Slovak Republic, discovering that this sector is fully resistant to innovative marketing activities, which aim to increase subjectively perceived brand value.
In general, one can state that a review of scientific studies confirms that according to most research papers on the evaluation of the effectiveness of the marketing activities of banks, there is no integrated approach, and the developed systems of indicators do not take all the factors that affect the level of marketing activity into account. This confirms the relevance and expediency of continuing research in this area and developing theoretical and applied provisions regarding the estimation of the level of marketing activity of the banking structures of Ukraine. The individual approach based on the national specifics of the banking sector in a selected country is based on the fact that the significant discrepancies between consumers' socio-cultural profiles as a main factor in the effectiveness of marketing activities has been proven (Kliestikova and Janoskova, 2017). Thus, it can be stated the uniform approach to the application of marketing activities without taking into account national specifics is a significant barrier to the effectiveness of marketing management. This fact highlights the need for the creation of an optimal methodology for assessing the level of bank marketing activity and the effectiveness thereof, so that the effectiveness of marketing activities can be monitored constantly and any possible undesirable trends can be detected before the subjectively perceived brand value is reduced from the perspective of the consumer (Valaskova et al., 2018).

Having analyzed the scientific literature, one should note that some scholars state that, for the overall estimation of bank marketing activity, it is sufficient to estimate only one of the areas of the marketing system. For example, a significant number of scientific sources are devoted to the impact on the effectiveness of bank marketing activities in terms of promotion methods (communications with clients) (Montgomery and Silk, 1972; Edell and Keller, 1999; Ahmed et al., 2017, see also Schüller et al., 2013); and marketing costs aimed at sales and promotion (Valentyn and Pavlov, 2017; Csikósová et al., 2016). The importance of creating a qualitative brand of the product shall be estimated (i.e. attention shall be focused on the product policy as a factor in the activation of bank marketing) (Yoganathan et al., 2015), etc. As defined by Kotler (2007: 63), a marketingmix is a set of variable marketing factors that are subject to control, the aggregate of which is used by the company in order to trigger the desired reciprocal reaction from the target market. The marketing-mix includes everything which can help the company to influence the demand for its product. He distinguished four components of the marketing-mix: product, price, methods of distribution and promotion. Research shows that the ability to correctly combine elements of the marketing-mix is the basis of success in solving marketing problems. Partial indicators allow us to 
evaluate the positive or negative trends in the state of each element of the marketing-mix. However, for systematic and integrated estimation of the level of bank marketing activity, it is necessary to integrate all partial indicators of each of the elements, which allows us to take the impact of all marketing activities and instruments into account in terms of goal achievement.

The review of the scientific studies confirms that the complex approach is absent and not all the factors influencing the efficiency of the bank's marketing activity have been taken into account. It makes necessary to develop approaches in assess the level of bank's marketing activity, by considering all elements of the marketing mix, and to establish the level of marketing activity of state-owned banks in comparison with the private banks of Ukraine for the period 2016-2107 in the rating table.

\section{MATERIALS AND METHODS}

\section{Methodology and Data Construction}

Existing dilemmas in the estimation of the marketing activity of banking structures provide the basis for a further contribution to solving this problem. In particular, it relates to the development of the construct for its assessment which might be applicable under changing environmental conditions. In order to objectively determine the bank marketing activity, it is necessary to take all areas of the marketing-mix and their respective partial indicators into account. Under such conditions, the calculation of a comprehensive estimation of bank marketing activity is best done by defining an integral indicator. The calculation of the level of bank marketing activity, based on the definition of the integral indicator, could be carried out in the following sequence (Fig. 1).

The stages shown in Fig. 1 reveal the actions that must be performed to determine the level of bank marketing activity through the prism of calculating the integral indicator. The content of each of these steps will be thoroughly described below.

The first stage of the proposed sequence of calculating the level of bank marketing activity involves the selection of partial indicators of marketing activity evaluation for each of the four elements of the marketing-mix. Thus, revealing the essence of this stage, we note that in order to assess bank marketing activity it makes sense to consider a group of indicators that will help to depict its level more effectively when calculating the integral index. Such indicators which have a quantitative measurement should be primarily considered. It is better to select them on the basis of the elements of the marketing-mix, namely "Product", "Price", "Sales", and "Promotion".

The list of partial indicators for calculating the integral index of bank marketing activity is presented in Tab. I The indicators are grouped by each of the four elements of the marketing-mix: indicators for product, sales, pricing and promotion policies (advertising).

The second stage involves determining the course of changes in indicators, that is, the division of all indicators into boosters and disincentives.

Indicators-boosters are indicators whose growth contributes to an increase in the integral index of bank marketing activity. Indicators-disincentives are indicators whose growth contributes to a decrease in the integral index of bank marketing activity (Tab. I, column "The course of changes").

The next important step is to determine the importance of indicators as envisaged at the third stage. Therefore, in order to determine the importance of indicators for estimating bank marketing activity, we suggest using the method of hierarchy analysis (Saaty method) (Saaty, 1993: 53), which provides for the calculation of vectors of alternative priorities in relation to the selected

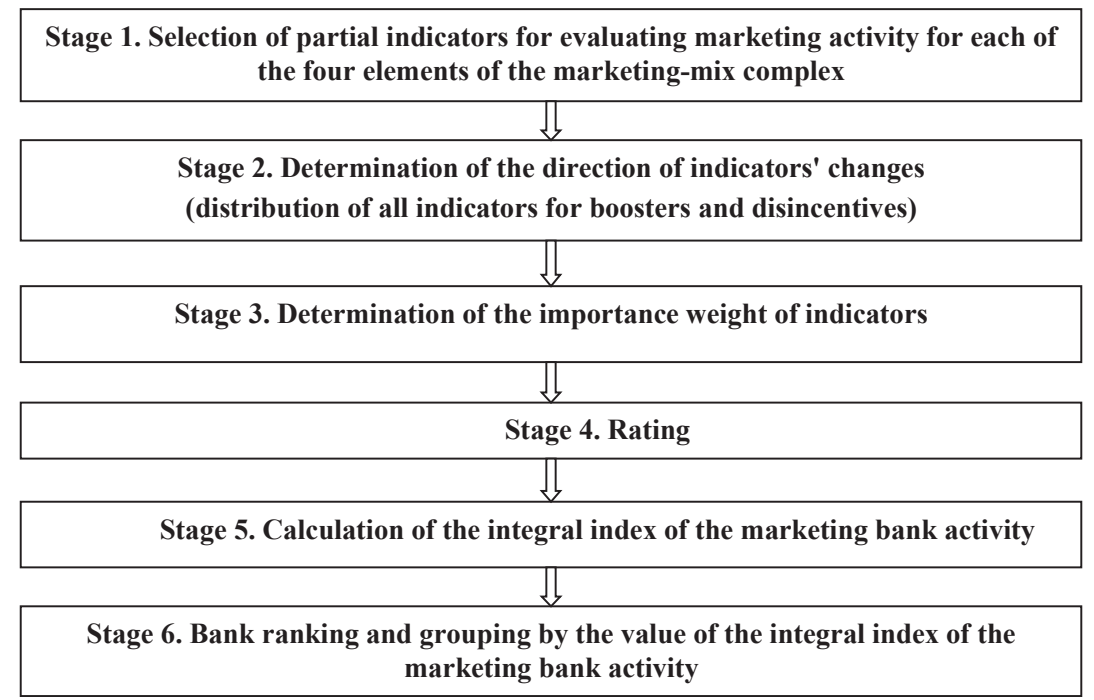

1: Sequence of calculation of the level of bank marketing activity 


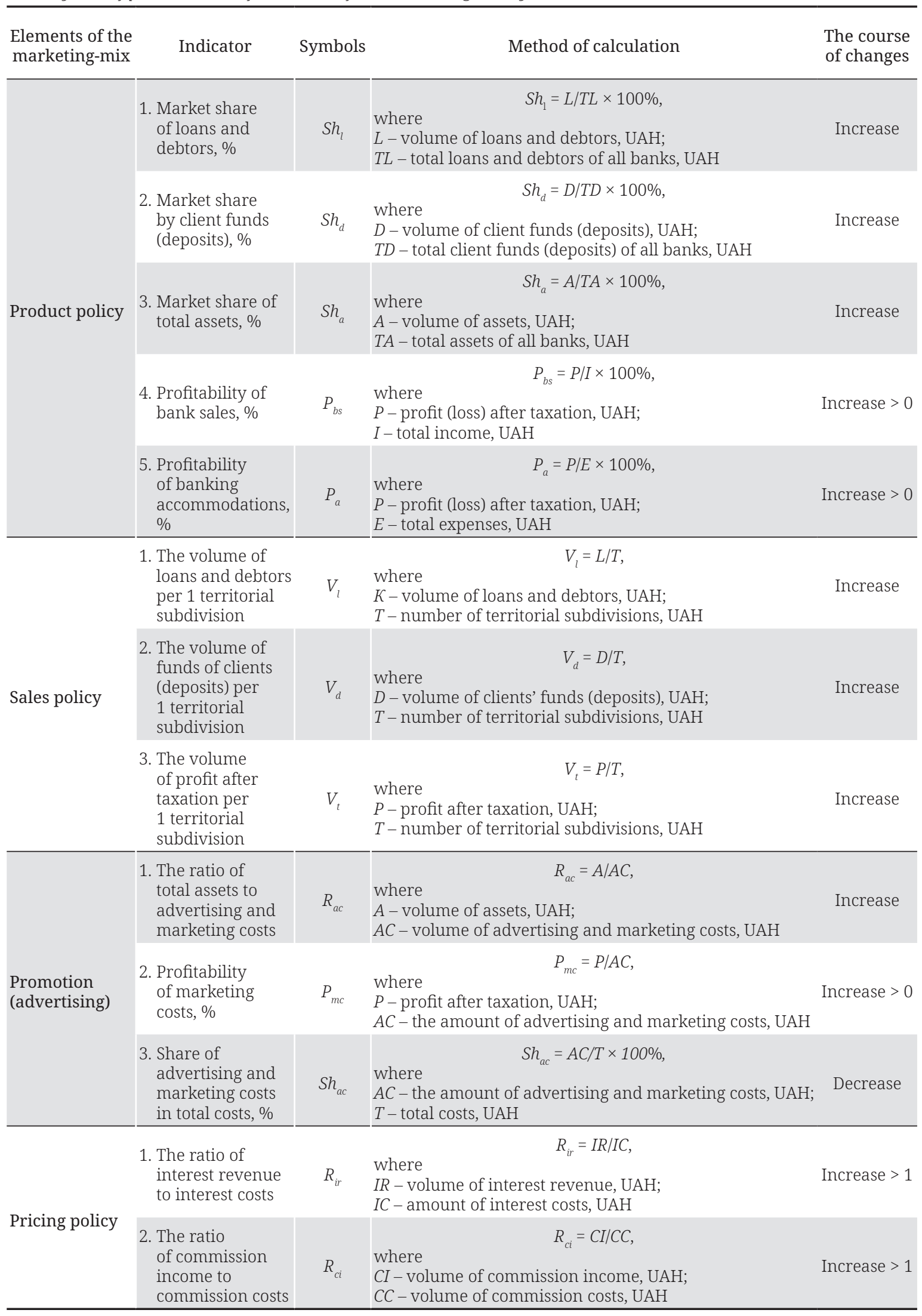


II: The scale of the relative importance of the method of hierarchy analysis by Saaty (1993: 53)

\begin{tabular}{cll}
\hline Grade, $\mathrm{k}$ & \multicolumn{1}{c}{ Definition } & \multicolumn{1}{c}{ Characteristic } \\
\hline 1 & Equal importance & Equal contribution of the two elements to the overall estimation \\
3 & Moderate advantage & Clear advantage of one element over another \\
5 & Significant advantage & A substantial advantage of one element over another \\
7 & Significant advantage & Practically significant advantage of one element over another \\
\hline $2,4,6,8$ & Intermediate values & The obvious advantage is the domination of one element over another \\
$1 / \mathrm{k}$ & The value of symmetric elements & Used to evaluate non-dominant elements \\
\hline Source: &
\end{tabular}

Source: Saaty, 1993

criteria. Pair-wise comparisons are defined as an advantage of one element over the other according to the scale of relative importance (Tab. II).

To determine the weight of elements of the marketing-mix, a matrix of pair-wise comparisons with the definition of local priorities shall be established. The criteria and the importance thereof shall be determined on the basis of expert estimation. The experts were 32 employees of the relevant departments of banks such as OSCHADBANK JSC, CB PRIVATBANK PJSC, UKREXIMBANK JSC, UKRGAZBANK JSB, REDOBANK PJSC, and UKRSOTSBANK PJSC. The experts proposed to compare the advantage of one element of the banking marketing-mix over the other by pairs according to the 10-point scale by Saaty.

The components of the vector of local priorities are calculated by Formulas 1-3 (Saaty, 1993: 216):

$$
\begin{aligned}
& w_{i}=\frac{\overline{w_{i}}}{\sum_{i=1}^{n} \overline{w_{i}}} ; \quad i=\overline{1, n} ; \\
& \overline{W_{i}}=\sqrt[n]{\prod_{j=1}^{n} a_{i j}} ; \quad i=\overline{1, n},
\end{aligned}
$$

where $\mathrm{a}_{\mathrm{ij}}-i$-th element of the $j$-th column matrix of pair-wise comparison of the elements, $n$ - the number of the elements compared.

The maximal proper value of the inversesymmetric matrix of pair-wise comparisons is determined by the following formula:

$\lambda_{\max }=\sum_{j=1}^{n} w_{j}\left(\sum_{i=1}^{n} a_{i j}\right)$

The estimation of the relative importance of the elements to be compared should be consistent; therefore, the index (IC) of consistency and the ratio (RC) of consistency (optimal value of RC $<10 \%$ ) are determined by Formulas 4-5 (Saaty, 1993: 23-25):

$C I=\frac{\lambda_{\max }-n}{n-1}$

$R C \frac{I C}{R I C}$

The values of the random coherence index (RIC) of the advantages, depending on the number of elements being compared, are selected from Tab. III.

III: The value of the random coherence index according to Saaty (1993: 25)

\begin{tabular}{ccccccccccc}
\hline $\mathrm{n}$ & 1 & 2 & 3 & 4 & 5 & 6 & 7 & 8 & 9 & 10 \\
\hline $\mathrm{RIC}$ & 0.00 & 0.00 & 0.58 & 0.90 & 1.12 & 1.24 & 1.32 & 1.41 & 1.46 & 1.49 \\
\hline
\end{tabular}

\begin{tabular}{|c|c|c|c|c|c|c|}
\hline \multirow{2}{*}{ No. } & \multirow{2}{*}{ Elements of the marketing-mix } & \multicolumn{4}{|c|}{ Criteria number } & \multirow{2}{*}{ Vector of local priorities (weight), $w_{i}$} \\
\hline & & 1 & 2 & 3 & 4 & \\
\hline 1 & Product policy & 1 & 7 & 5 & 4 & 0.588 \\
\hline 2 & Sales policy & $1 / 7$ & 1 & 6 & 6 & 0.216 \\
\hline 3 & Pricing policy & $1 / 5$ & $1 / 6$ & 1 & 5 & 0.112 \\
\hline 4 & Promotion (advertising) & $1 / 4$ & $1 / 6$ & $1 / 5$ & 1 & 0.084 \\
\hline
\end{tabular}

IV: Matrix of pair-wise comparisons for elements of the marketing-mix

$\lambda \max =4.315 ; \mathrm{IC}=0.105 ; \mathrm{RC}=0.117 \leq 0.1$

Source: prepared and calculated by the authors on the basis of expert estimation 


\section{RESULTS AND DISCUSSION}

Based on the methodology presented above, the following results were obtained.

The experts proposed to compare the advantages of the indicators for each of the four elements of the marketing-mix of the bank over other indicators of the corresponding element according to the 10-point scale by Saaty (Tab. II). The results of pairwise comparisons and the determination of the local priorities (significance) for the indicators for each of the elements of the marketing-mix are given in Tabs V-IX.
The summarized results of determining the importance weight of indicators on the basis of expert evaluation using the method of hierarchy analysis are presented in Tab. IX.

Thus, the calculation of the importance of partial indicators for evaluating marketing activity for each of the four elements of the marketing-mix, as shown in Tab. IX, is the result of completing the third stage of the proposed sequence.

At the fourth stage, the valuation of indicators is carried out. Given that the overwhelming majority of indicators of economic development are specific values, a necessary measurement procedure is the

V: Matrix of pair-wise comparisons for indicators of the element of the marketing-mix "Product Policy"

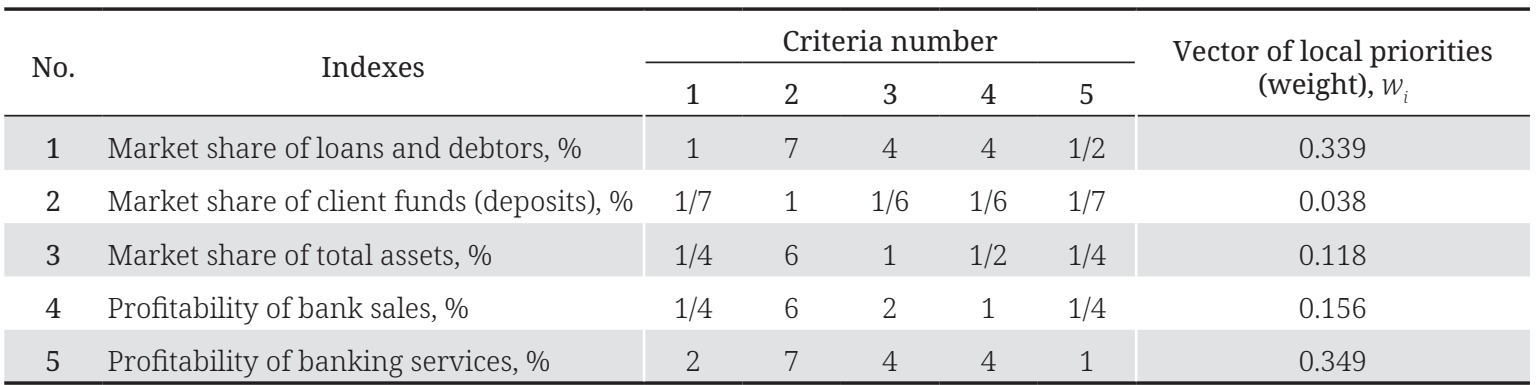

$\lambda \max =5.198 ; \mathrm{IC}=0.035 ; \mathrm{RC}=0.031<0.1$

Source: prepared and calculated by the authors on the basis of expert estimation

VI: Matrix of pair-wise comparisons for indicators of the element of the marketing-mix "Sales Policy"

\begin{tabular}{|c|c|c|c|c|c|}
\hline No. & Indexes & \multicolumn{3}{|c|}{ Criteria number } & $\begin{array}{c}\text { Vector of local priorities } \\
\text { (weight), } w_{i}\end{array}$ \\
\hline 2 & Volume of client funds (deposits) per 1 territorial subdivision & $1 / 3$ & 1 & $1 / 6$ & 0.085 \\
\hline 3 & Amount of profit after taxation per 1 territorial subdivision & 6 & 6 & 1 & 0.738 \\
\hline
\end{tabular}

$\lambda \max =3.136 ; \mathrm{IC}=0.068 ; \mathrm{RC}=0.117 \leq 0.1$

Source: prepared and calculated by the authors on the basis of expert estimation

VII: Matrix of pair-wise comparisons for indicators of the element of the marketing-mix "Promotion (advertising)"

\begin{tabular}{|c|c|c|c|c|c|}
\hline No. & Indexes & \multicolumn{3}{|c|}{ Criteria number } & $\begin{array}{c}\text { Vector of local priorities } \\
\text { (weight), } w_{i}\end{array}$ \\
\hline 2 & Cost effectiveness of marketing costs, \% & 4 & 1 & 2 & 0.537 \\
\hline 3 & The share of advertising and marketing costs in total costs, \% & 5 & $1 / 2$ & 1 & 0.364 \\
\hline
\end{tabular}

$\lambda \max =3.094 ; \mathrm{IC}=0.047 ; \mathrm{RC}=0.081<0.1$

Source: prepared and calculated by the authors on the basis of expert estimation

VIII: Matrix of pair-wise comparisons for indicators of the element of the marketing-mix "Pricing policy"

\begin{tabular}{|c|c|c|c|c|}
\hline \multirow[t]{2}{*}{ No. } & \multirow{2}{*}{ Indexes } & \multicolumn{2}{|c|}{$\begin{array}{l}\text { Criteria } \\
\text { number }\end{array}$} & \multirow{2}{*}{$\begin{array}{l}\text { Vector of local priorities } \\
\text { (weight), } w_{i}\end{array}$} \\
\hline & & 1 & 2 & \\
\hline 1 & Ratio of interest income to interest costs, \% & 1 & 2 & 0.667 \\
\hline 2 & Ratio of commission income to commission expenses, \% & $1 / 2$ & 1 & 0.333 \\
\hline
\end{tabular}

Source: prepared and calculated by the authors on the basis of expert estimation 
IX: Value of importance weight of partial indicators of marketing activity estimation for each of the four elements of the marketing-mix

\begin{tabular}{|c|c|c|c|}
\hline $\begin{array}{l}\text { Elements of the } \\
\text { marketing-mix }\end{array}$ & $\begin{array}{l}\text { The importance } \\
\text { weight of the } \\
\text { element of the } \\
\text { marketing-mix }\end{array}$ & Indicators for each of the elements of the marketing-mix & $\begin{array}{l}\text { Values of } \\
\text { indicators }\end{array}$ \\
\hline \multirow{5}{*}{ Product policy } & \multirow{5}{*}{0.588} & 1. Market share of loans and debtors, $\%$ & 0.339 \\
\hline & & 2. Market share of client funds (deposits), $\%$ & 0.038 \\
\hline & & 3. Market share of total assets, $\%$ & 0.118 \\
\hline & & 4. Profitability of bank sales, $\%$ & 0.156 \\
\hline & & 5. Profitability of banking services, $\%$ & 0.349 \\
\hline \multirow{3}{*}{ Sales policy } & \multirow{3}{*}{0.216} & 1. Volume of loans and debtors per 1 territorial subdivision & 0.177 \\
\hline & & 2. Volume of client funds (deposits) per 1 territorial subdivision & 0.085 \\
\hline & & 3. Amount of profit after taxation per 1 territorial subdivision & 0.738 \\
\hline \multirow{3}{*}{$\begin{array}{l}\text { Promotion } \\
\text { (advertising) }\end{array}$} & \multirow{3}{*}{0.084} & 1. Ratio of total assets to advertising and marketing costs, $\%$ & 0.099 \\
\hline & & 2. Cost effectiveness of marketing costs, $\%$ & 0.537 \\
\hline & & 3. The share of advertising and marketing costs in total costs, $\%$ & 0.364 \\
\hline \multirow{2}{*}{ Pricing policy } & \multirow{2}{*}{0.112} & 1. Ratio of interest income to interest costs, $\%$ & 0.667 \\
\hline & & 2. Ratio of commission income to commission expenses, $\%$ & 0.333 \\
\hline
\end{tabular}

Source: prepared and calculated by the authors on the basis of expert estimation

preliminary valuation of the selected indicators, which ensures the comparison and matching of the established database. Rationing is performed according to different formulas for boosters and disincentives. This is due to the need to unify those components in which the ranking is carried out from the maximum to the minimum values, and those in which it is carried out in the opposite direction.

The rating of indicators is proposed in accordance with the methodology for calculating integrated regional indices of economic development, approved by the order of the State Statistics Committee of Ukraine (Method of Calculation):

- for indicators-boosters:

$Y_{i j}=\frac{Z_{i j}-Z_{\min }}{Z_{\max }-Z_{\min }}$,

where $Z_{i j}$ - is value of $i$-th Indicator for $j$-th bank; $Z_{\min }$ - the minimum value of the i-th indicator for all banks; $Z_{\text {maz }}$ - the maximum value of the $\mathrm{i}$-th indicator for all banks.

- for indicators-disincentives:

$Y_{i j}=\frac{Z_{\max }-Z_{i j}}{Z_{\max }-Z_{\min }}$.

The results of the above preliminary studies give the basis for calculating the integral index of bank marketing activity, which is foreseen at the fifth stage of the proposed sequence.

Revealing the economic essence of the fifth stage, it should be noted that in order to calculate bank marketing activity, the use of the integral index method $\left(I_{m b}\right)$ is proposed, since this method allows the researchers to take the integral indicators of all elements of the marketing-mix and their weighting factors into account (8):

$I_{m b}=I_{p p} \times v_{s p}+I_{s p} \times v_{s p}+I_{p a} \times v_{p a}+I_{p a} \times v_{p a}$,

where $I_{m b}$ - integral index of marketing activity of the bank; $I_{p p}$ - integral activity index of the bank product policy; $\stackrel{p p}{I}_{s p}$ - integral activity index of the bank sales policy; $I_{\mathrm{pa}}$ - integral activity index of the policy of promotion and advertising of the bank; $I_{t s}$ - integral activity index of the bank pricing policy; $v_{p p}, v_{s p}, v_{p a}$ $v_{p p}$ - weights of integral activity indexes of product, sales, promotion and advertising and pricing policy respectively.

The calculation of integral indexes of each element of the marketing-mix, including activity index of the product policy $\left(\mathrm{I}_{\mathrm{pp}}\right)$, the sales policy $\left(\mathrm{I}_{\mathrm{sp}}\right)$, the policy of promotion and advertising $\left(\mathrm{I}_{\mathrm{pa}}\right)$ and the pricing policy $\left(\mathrm{I}_{\mathrm{pp}}\right)$, is determined by the formulas:

$I_{n n}=\sum_{i=1}^{n} a_{n n i} \times S_{n n i}$,
$I_{3 n}=\sum_{i=1}^{n} a_{3 n i} \times S_{3 n i}$,

$I_{p n}=\sum_{i=1}^{n} a_{p n i} \times S_{p n i}$,

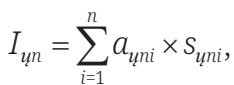




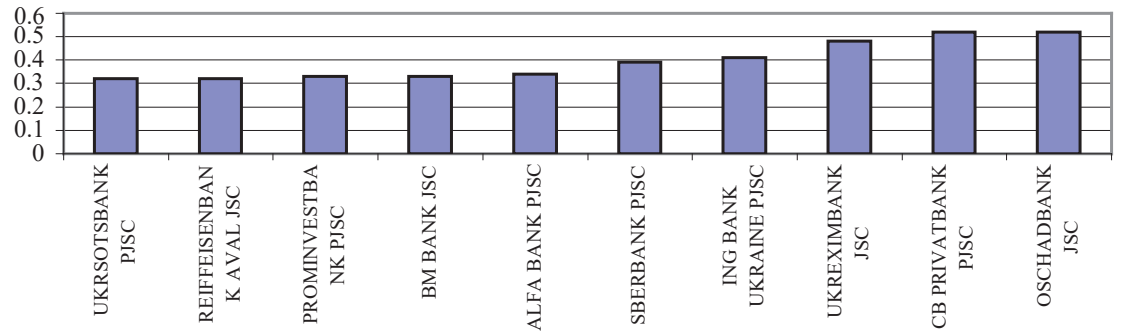

2: Positioning of banks by the value of the index of marketing activity, 2016

Source: constructed on the basis of the author's calculations

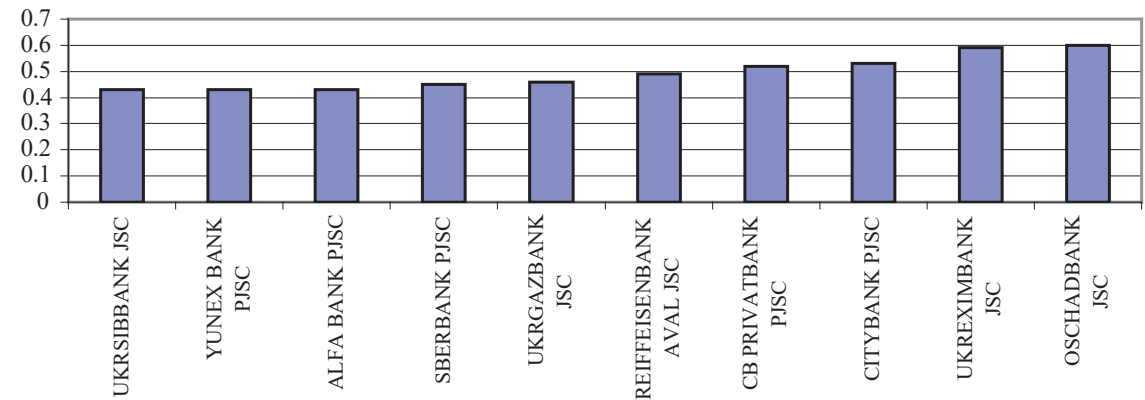

3: Positioning of banks by the value of the index of marketing activity, 2017

Source: constructed on the basis of the author's calculations

where $a_{p p}, a_{s p}, a_{p a}, a_{p p}$ - volume of weight of the $i$-th partial indicator, determined using the hierarchy analysis for the product policy, the sales policy, the policy of promotion and advertising and pricing policy accordingly; $s_{p p}, s_{s p}, s_{p a}, s_{p p}$ - normalized values of the $i$-th partial indicator for the product policy, the sales policy, the policy of promotion and advertising and pricing policy accordingly; $\mathrm{n}$ - the number of partial indicators in the investigated element of the marketing-mix.

The range of the integral index of the bank marketing activity varies from 0 to 1 . The higher the value of this index, the higher the level of bank marketing activity and vice versa.

The sixth stage is the final one, in which the ranking and grouping of banks are performed in terms of the integral index of bank marketing activity.

In order to calculate the integral index of bank marketing activity, indicators of the financial activity of banks (Banking System Indicators) which are published on the official site of the National Bank of Ukraine are used (indicators are formed according to data submitted to the National Bank of Ukraine in accordance with the Instruction on the procedure for preparation and publication of financial reporting of Ukrainian banks approved by the Resolution of the Board of the National Bank of Ukraine dated 24 October 2011, No. 373, as amended).

The sample includes all banks licensed by the National Bank of Ukraine for the period during which the survey was conducted. Generally, the sample includes 5 state-owned banks in 2016-2017, 85 private banks in 2016 and 79 private ones in 2017.
The analysis which was conducted according to data from 2016-2017 included 90 banks in 2016 and 84 banks in 2017. The decrease in the number of banks for the analyzed period is substantiated by the introduction of the regime of bank liquidation or their exclusion from the State Register. According to the results of the calculations, which are based on the proposed method, the results obtained are graphically interpreted (Figs. 2-3). According to the results of the ranking, the top 10 banks with the highest value of the index of marketing activity according to the results of 2016-2017 are presented.

The results of the study revealed that during 2016-2017, OSCHADBANK JSC, CB PRIVATBANK PJSC, UKREXIMBANK JSC (Ukrainian state banks) maintained consistently high positions in the ranking of Top 10 banks by marketing activity level. In 2017, another state bank of Ukraine, UKRGAZBANK JSC, improved its position, rising from $13^{\text {th }}$ to $6^{\text {th }}$ position.

Harrington's Universal Scale was used to group banks and evaluates their level of marketing activity (Harrington, 1965: 494-498). The level of bank marketing activity will be determined depending on the value of the integral index of the bank marketing activity $\left(I_{m b}\right)$ (Tab. X).

Only five banks (OSCHADBANK JSC, CB PRIVATBANK PJSC, UKREXIMBANK JSC, ING BANK UKRAINE PJSC, and SBERBANK PJSC) could be classified as having an average level of marketing activity according to the data from 2016; the remaining banks exhibited a low level of marketing activity. According to the results from 2017, 26 banks had an average level of marketing activity, 
X: Characteristics of bank marketing activity levels according to the Harrington scale

\begin{tabular}{c}
$\begin{array}{c}\text { Harrington } \\
\text { Scale Intervals } \\
\text { (range of } \mathrm{M}_{\mathrm{Mb}} \text { ) }\end{array}$ \\
\hline (0.8-1]
\end{tabular}

Source: proprietary authors' design

indicating an improvement in the functioning of the financial markets, the gradual restoration of the banking system and an improvement of the competitiveness of banks on financial markets.

According to the results of the study, a system of measures has been developed to raise the level of the marketing activity of the banking structures (Tab. XI).

Thus, Tab. XI shows the grading of possible levels of marketing activity of banking structures by the authors and the appropriate measures to increase them. Determining the level of bank marketing activity as well as selection and implementation of the proper proposed measures will help the management boards to bring the banks to a qualitatively new level of functioning and strengthen their respective competitive positions on the banking market.

\section{CONCLUSION}

The article develops theoretical and applied provisions for estimating the level of bank marketing activity on the basis of the integral index definition. The calculation of the integral index of the level of bank marketing activity is an important direction in estimating the state and level of development of the marketing-mix in banks. The index allows one to detect and quickly eliminate deviations in the achievement of sales goals and objectives, the implementation of promotional activities, and product and pricing policies, which affect the overall efficiency of financial banking activities.

In the proposed methodology for assessing the level of bank marketing activity, we highlighted two major advantages compared to the methods proposed by other scholars, the first of which was complexity and integrality. Many scholars consider the appropriate criteria for the effectiveness of bank marketing activities to be not a set of indicators, but rather a certain indicator. For example, Melchinger (1992) considers profitability to be the only criterion for measuring marketing effectiveness if improved sales figures are achieved. Other scholars investigate the effectiveness of bank marketing activities in view of multiple financial indicators without integrating them into a whole (Naser and Moutinho, 1997; Csikósová et al., 2016), or study the impact of each of the partial indicators on the overall result without considering their complexity (Basheer et al., 2010; Mahmood 
XI: Measures to raise the level of bank marketing activity

\begin{tabular}{|c|c|}
\hline $\begin{array}{l}\text { The level of bank } \\
\text { marketing activity }\end{array}$ & Measures to raise the level of bank marketing activity \\
\hline Significant level & $\begin{array}{l}\text { - introduction of innovations in marketing activity; } \\
\text { - application of non-traditional marketing tools for the promotion of banking products; } \\
\text { - implementation of the concept of an individual approach to key customers; } \\
\text { - use of progressive international experience in marketing activities; } \\
\text { - opening of new territorial subdivisions, entry into new markets; } \\
\text { - strengthening of the promotion system of target consumers. }\end{array}$ \\
\hline Sufficient level & $\begin{array}{l}\text { - increased financing of marketing actions; } \\
\text { - improvement of stimulation methods of clients and bank employees; } \\
\text { - improvement of monitoring the implementation of marketing plans; } \\
\text { - improvement of banking market segmentation. }\end{array}$ \\
\hline Normal level & $\begin{array}{l}\text { - improvement of the bank marketing service; } \\
\text { - } \text { advanced training for employees of the marketing department; } \\
\text { - improving the methods of advertising and public relations; } \\
\text { - application of differential marketing strategy; } \\
\text { - strengthening of the advertising campaign; } \\
\text { - constant research on competitors' activity. }\end{array}$ \\
\hline Satisfactory level & $\begin{array}{l}\text { - partial reorganization of the marketing service; } \\
\text { - studying the needs of customer-clients; } \\
\text { - optimization of advertising and marketing expenses; } \\
\text { - responsible attitude of banks in their duty to the clients; } \\
\text { - review and improvement of the current marketing strategy; } \\
\text { - formation of unscheduled reserves for credit operations. }\end{array}$ \\
\hline Critical level & $\begin{array}{l}\text { - formation of a new marketing strategy; } \\
\text { - reorganization of marketing services at the bank; } \\
\text { - establishment of the effective system of gathering information on changes taking place in the } \\
\text { - reduction of advertising and marketing expenses; } \\
\text { - search for new potential markets; } \\
\text { - formation of financial reserves in order to ensure a stable financial position and guarantee the } \\
\text { safety of client funds. }\end{array}$ \\
\hline
\end{tabular}

Source: proprietary authors' design

and Khan, 2014). By contrast, in our study all the most important aspects of the bank marketing activity (i.e. the four components of the marketing-mix: product, price, distribution and promotion methods) have been evaluated, whose mutual influence on the achievement of goals is reflected in the integral indicator. By using the value of the integral indicator, it is possible to draw conclusions about the effectiveness of marketing activity as a separate element and marketing in general.

The second advantage is significance, which allows the force of the influence of each of the partial indicators on the integral indicator and the specificity of the studied area to be taken into account. Unfortunately, many scholars ignore the importance of assessing the effectiveness of banking structures, including marketing (Bhattacharyya, et al., 1997), which may distort the results of the study towards the predominance of one factor. For example, in research by Řepková (2014) which evaluated the performance of Czech banks in the period 2003-2012, the findings were that the causes of inefficiency of large banks were in excess of deposits in the balance sheet and inappropriate size of transactions, which reduced their efficiency compared to other banks. Our proposal allows researchers to avoid such a situation.

One should also underline the application value of the paper. The theoretical and applied provisions for estimating and raising the level of bank marketing activity can be applied in practice. Moreover, it may be useful to formulate plans and strategies for the development of the state, region or bank to improve the efficiency of the banking sector as a prerequisite for increasing the competitiveness of the Ukrainian financial system. The measures proposed to estimate and increase the level of bank marketing activity will allow banks to strengthen their competitive positions, identify and timely eliminate factors that negatively affect the level of marketing activity, find and strengthen the narrow lines of marketing activity, as well as reach a new level of innovation development. 
It should be emphasized that the proposed method makes it possible to identify and rank the state and private banks of Ukraine by the level of marketing activity. According to the results, state-owned banks of Ukraine occupy rather a high position in the rating. In 2016, the first three positions in the top 10 rank were held by state-owned banks: OSCHADBANK JSC, CB PRIVATBANK PJSC, UKREXIMBANK JSC. In 2017, however, the situation was as follows: CB PRIVATBANK PJSC moved to the fourth position, UKREXIMBANK JSC moved to the second position. Another Ukrainian state-owned bank - UKRGAZBANK JSC - improved its position and rose up from $13^{\text {th }}$ position to the $6^{\text {th }}$ one in 2017. High rankings of state-owned banks during the period of 2016-2107 indicate their effective product, marketing, pricing and promotion policies. In other words, state-owned banks in Ukraine are more active in marketing than private banks. Given this fact, it is recommended that the private banks should analyse in details the strategies implemented by the stated owned banks (benchmarking) and, if applicable, try to adopt them, at least to some extent.

Our paper has certain limitations. First of all, one has to state that the method of calculating marketing activity as a tool for identifying "weak points" and a guideline for developing a system of certain measures to increase the level of marketing activity of research subjects and their level of competitiveness is not effective when it comes to practical application by social, medical and industrial enterprises, as each of them has their own peculiarities of functioning, different key indicators and different weights when calculating marketing activity. Another limitation is the national coverage, as the analysis was carried out in only one country, whose banking sector is not as well developed as in the case of Western countries. Despite these limitations, we believe that the method applied in our study allowed us to present the real picture of the situation in the sector analyzed.

In the future, it will be necessary to make the research in this area more profound by analyzing the dynamics of integral indicators of the level of bank marketing activity, which will allow researchers to identify the development of or efficiency regression trends in the marketing activity of banking structures for a certain period of time, to identify crisis states in the life cycle of banking activity, as well as modeling to predict the direction of development of the individual bank and the banking system as a whole in terms of marketing activity.

\section{REFERENCES}

AHMED, R., VVEINHARDT, J., ŠTREIMIKIENĖ, D., ASHRAF, M. and CHANNAR, Z. 2017. Modified SERVQUAL model and effects of customer attitude and technology on customer satisfaction in banking industry: mediation, moderation and conditional process analysis. Journal of Business Economics and Management, 18(5): 974-1004.

AL-ALAK, B. A. 2014. Impact of marketing activities on relationship quality in the Malaysian banking sector. Journal of Retailing and Consumer Services, 21(3): 347-356.

ALAEDDIN, O., RANA, A., ZAINUDIN, Z. and KAMARUDIN, F. 2018. From physical to digital: Investigating consumer behaviour of switching to mobile wallet. Polish Journal of Management Studies, 17(2): 8-30.

ANDRONICEANU, A., GHERGHINA, R. and CIOBANANU, M. 2019. The interdependence between fiscal public policies and tax evasion, Administratie si Management Public, 32: 32-41.

ANDRONICEANU, A. 2017. The three-dimensional approach of Total Quality Management, an essential strategic option for business excellence, Amfiteatru Economic, 19(44), 61-78.

ASSENSOH-KODUA, A. 2016. Marketing potentials of the social media tools in the banking market of an emerging country. Risk Governance and Control: Financial Markets and Institutions, 6(4): 257-267.

BAKHANOVA, M. V. 2014. Analysis of the effectiveness of implementation of a complex of marketing communications by commercial banks of Ukraine. Collection of scientific works of the Tavrida State Agrotechnological University (Economic Sciences), 1: 42-48.

NATIONAL BANK OF UKRAINE. (C2019. Banking System Indicators. National Bank of Ukraine. [Online]. Available at: https://bank.gov.ua/control/en/publish/article?art_id=34661442 [Accessed: 2019, March 20].

BASHEER, A. M. AL-ALAK, I. and ALNAWAS, A. M. 2010. Evaluating the effect of marketing activities on relationship quality in the banking sector: the case of private commercial banks in Jordan. International Journal of Marketing Studies, 2(1): 78-91.

BHATTACHARYYA, A., LOVELL, C. A. K. and SAHAY, P. 1997. The impact of liberalization on the productive efficiency of Indian commercial banks. European Journal of Operational Research, 98(2): 332-345.

CHUKHRAY, N. I. and MLYNKO, I. B. 2013. Estimation of efficiency and effectiveness of marketing of industrial enterprise in the supply chain. Marketing and management of innovations, 3: 24-34. 
CSIKÓSOVÁ, A., ČULKOVÁ, K. and JANOŠKOVÁ, M. 2016. Evaluation of quantitative indicators of marketing activities in the banking sector. Journal of Business Research, 69(11): 5028-5033.

EDELL, J. E. and KELLER, L. 1999. Analyzing media interactions: the effects of coordinated TV-print advertising campaigns. Cambridge, MA: Marketing Science Institute.

FEICHTINGER, G., HARTL, R. F. and SETHI, S. 1994. Dynamic optimal control models in advertising: recent developments. Management Science, 40(2): 195-226.

GAIDUKOVICH, D. S. 2012. Marketing analysis of the competitiveness of Ukrainian banking institutions. Economic Bulletin of the National Mining University, 1: 117-122.

HARRINGTON, E. C. 1965. The desirability function. Industrial Quality Control, 21(10): 494-498.

JAFARI, M. 2016. Evaluation of the impact of services marketing-mix on customer preferences in selecting a bank in Khorramabad City. International Business Management, 10(10): 1851-1860.

KARYY, O. and KRYKAVSKYY, Y. 2016. Transformation of marketing in the era of digitization: particularities of digital marketing. In: BARCIK, A. HOWANIEC, H. and MALARA, Z. (Eds.), Selected aspects of management of contemporary enterprises. Bielsko-Biała: Akademia TechnicznoHumanistyczna w Bielsku-Bialej, pp. 7-15.

KHMARSKYI, V. Y. and PAVLOV, R. A. 2016. Ranking system for Ukrainian banks based on financial standing. Actual Problems of Economics, 184(10): 348-360.

KLIESTIKOVA J. and JANOSKOVA, K. 2017. Branding with understanding: how national profile of consumer influences brand value perception. Marketing and Management of Innovations, 3: 149157.

KLIESTIKOVA, J. and KOVACOVA, M. 2017. Motion to innovation: brand value sources have (not) changed over time. In: Proceedings from Innovative Economic Symposium 2017 (IES2017). Ceske Budejovice, Czech Republic. SHS Web of Conferences 39, Art. No. UNSP 01010.

KLIESTIKOVA, J., KOVACOVA, M. and KRIZANOVA, A. 2019. Brand value sources: Case study of bank brands in Slovak Republic. In: Sustainability from an Economic and Social Perspective: proceedings from $39^{\text {th }}$ International Scientific Conference on Economic and Social Development. Lisbon, Portugal, pp. 361-368.

KOT, S. and MEYER, N. 2018. Using social media as a tool in the learning process. In: $2^{\text {nd }}$ International Conference of Contemporary Issues in Theory and Practice of Management. Czestochowa University of Technology, 19-20 April 2018, pp. 313-320.

KOTLER, F. 2007. Fundamentals of marketing: A short course. Moscow: VILLIAMS Publishing House.

MAHMOUD, M. A., BLANKSON, C., OWUSU-FRIMPONG, N., NWANKWO, S. and TRANG, T. P. 2016. Market orientation, learning orientation and business performance: the mediating role of innovation. International Journal of Bank Marketing, 34(5): 623-648.

MAHMOOD, R. and KHAN, S. M. 2014. Impact of service marketing mixes on customer perception: a study on Eastern Bank Limited, Bangladesh. European Journal of Business and Management, 6(34): 164-172.

MELCHINGER, J. H. 1992. Rating sales for marketing effectiveness. Broker World, 12(10): 118-22.

LEGAL PORTAL. 2019. Method of calculation of integral regional indexes of economic development. [Online]. Available at: http://uazakon.com/documents/date_1a/pg_ibcnog/index.htm [Accessed: 2019, March 20].

MEYER, N., MEYER, D. F. and KOT, S. 2017. The development of a process tool for improved risk management in local government. Quality - Access to Success, 18(S1): 425-429.

MONTGOMERY, D. and SILK, A. 1972. Estimating dynamic effects of marketing communications expenditures. Management Science, 18(10): 485-501.

MULLAN, J., BRADLEY, L. and LOANE, S. 2017. Bank adoption of mobile banking: Stakeholder perspective. International Journal of Bank Marketing, 35(7): 1154-1174.

NASER, K. and MOUTINHO, L. 1997. Strategic marketing management: the case of Islamic banks. International Journal of Bank Marketing, 15(6): 187-203.

PAKURÁR, M., HADDAD, H., NAGY, J., POPP, J. and OLÁH, J. 2019A. The service quality dimensions that affect customer satisfaction in the Jordanian banking sector. Sustainabilty, 11(4): 1113.

PAKURÁR, M., HADDAD, H., POPP, J., KHAN, T. and OLÁH, J. 2019b. Supply chain integration, organizational performance and balanced scorecard: An empirical study of the banking sector in Jordan. Journal of International Studies, 12(2): 129-146.

PURIWAT, W. and TRIPOPSAKUL, S. 2017. The impact of e-service quality on customer satisfaction and loyalty in mobile banking usage: Case study of Thailand. Polish Journal of Management Studies, 15(2), 183-193.

ŘEPKOVÁ, I. 2014. Efficiency of the Czech Banking sector employing the DEA window analysis approach, Procedia Economics and Finance, 12: 587-596. 
ROUMIEH, A., GARG, L., GUPTA, V. and SINGH, G. 2018. E-marketing strategies for Islamic banking: a case based study. Journal of Global Information Management, 26(4): 67-91.

SAATI, T. 1993. Decision making. Method of hierarchy analysis. Moscow: Radio and Communication.

SCHÜLLER, D., RAŠTICOVÁ, M. and KONEČNÝ, Š. 2013. Measuring student satisfaction with the quality of services offered by universities - Central European View. Acta Universitatis agriculturae et silviculturae Mendelianae Brunensis, 61(4): 1105-1112.

SHA, N. and MOHAMMAD, S. 2017. Virtual banking and online business. Bank and Bank Systems, 12(1): 75-81.

SHPAK, N., KYRYLYCH, T. and GREBLIKAITĖ, J. 2016. Diversification models of sales activity for steady development of an enterprise. Sustainability, 8(4): 393.

STRUPINSKA, N. V. 2013. Methodical approach to ensuring the effectiveness of marketing activity of an industrial enterprise. Business Inform, 8: 379-387.

VALASKOVA, K., KLIESTIKOVA, J. and KRIZANOVA, A. 2018. Consumer perceptions of private label products: an empirical study. Journal of Competitiveness, 10(3): 149-163.

VALENTYN, K. and PAVLOV, R. 2017. Relation between marketing expenses and bank's financial position: Ukrainian reality. Benchmarking, 24(4): 903-933.

VEJAČKA, M. 2017. Social media marketing in comparison with other forms of marketing in the Slovak banking sector. Market-Trziste, 29(1): 23-38.

VESELOVA, M. Y. 2014. New tendencies of marketing activity of commercial banks: Foreign experience. Sustainable Development of Economy, 3: 217-222.

YOGANATHAN, D., JEBARAJAKIRTHY, C. and THAICHON, P. 2015. The influence of relationship marketing orientation on brand equity in banks. Journal of Retailing and Consumer Services, 26: $14-22$.

Contact information

Nestor Shpak: dida_05@ukr.net

Ihor Kulyniak: ihor.y.kulyniak@lpnu.ua

Maryana Gvozd: gvozd-m@ukr.net

Yuliya Malynovska: yuliia.b.molochnyk@lpnu.ua

Włodzimierz Sroka: wsroka@wsb.edu.pl 